\title{
Advance Control Scheme for Desalination Plant
}

\author{
T. R. Rangaswamy, S. Prakash, Rathika R
}

\begin{abstract}
The multistage flash desalination (msf) process is used to separate brine from sea water and provide distilled water. The factors that determine the performance of the plant (distillate produced) depends on the output temperature of the brine heater which is known as top brine temperature.Single loop controllers are usually used to control top brine temperature. Control of top brine temperature of MSF plants is a multivariable control problem, due to interaction between other variables like, brine inlet flow to the brine heater, brine heater level, brine concentration etc., the use of simple PID controllers cannot cope with the compound interactions with other variables which affects the top brine temperature. Hence it is necessary to have dependable model of the plant behavior to account for the interaction between the controlled and manipulated variables. For this purpose, a non-linear dynamic model was developed for the MSF plant with multi variable interaction approach. Simulation studies were carried out to maintain top brine temperature by varying brine flow and brine heater level. A feed forward controller was developed and the performance was compared with the conventional PID controller. The merits of the proposed scheme were highlighted. [19],[20],[21]
\end{abstract}

Keywords : TBT (top brine temperature), Multistage flash $(\mathrm{MSF})$..

\section{INTRODUCTION}

Desalination is a detachment procedure used to diminish the broke up salt substance of saline water to a usable level. Multi-arrange streak refining (MSF) is a water desalination process that distils ocean water by glimmering a part of the water into steam in various stages. The plant comprises of two primary areas, to be specific Heat dismissal segment (3 phases) and Heat recuperation segment (19 phases). The recuperation stages comprises of a few back to back stages (vanishing chambers) kept up at diminishing weights from the principal arrange (hot) to the last organize (cold). Ocean water courses through the containers of the warmth exchangers where it is warmed by buildup of the vapor delivered in each stage. Its temperature increments from ocean temperature to delta temperature of the saline solution warmer. The ocean water at that point courses through the saline solution warmer where it gets the warmth fundamental for the procedure (by and large by gathering steam). At the outlet of the [14],[16], [18]

saline solution radiator, when entering the main cell,

Revised Manuscript Received on August 22, 2019.

Dr.S.Prakash, Professor, Department of EEE, Bharath Institute of Higher education and research, Tamilnadu, India

Rathika R, Assistant Professor, Department of EEE, Bharath Institute of Higher education and research, Tamilnadu, India.

Dr.T.R.Rangaswamy, Professor, Department of EEE,Bharath Institute of Higher education and research, Tamilnadu, India ocean water is overheated contrasted with the temperature and weight of stage 1 . Along these lines it will quickly "streak" ie discharge warmth, and consequently vapor, to arrive at balance with stage conditions. The delivered vapor is consolidated into new water on the cylindrical exchanger at the highest point of the stage. The procedure happens again when the water is brought into the accompanying stage, etc until the last and coldest stage. The cumulated new water develops the distillate creation which is removed from the coldest stage. Ocean water somewhat thinks from stage to stage and develops the salt water stream which is removed from the last stage.[3]

The MSF procedure can be part into various operational framework dependent on its capacity. They are Sea water framework, Brine water framework, Distillate water framework, Steam framework, Vacuum framework, Condensate framework, Blow down framework. The square chart of various operational frameworks in MSF plant is appeared[13], [15], , 17]

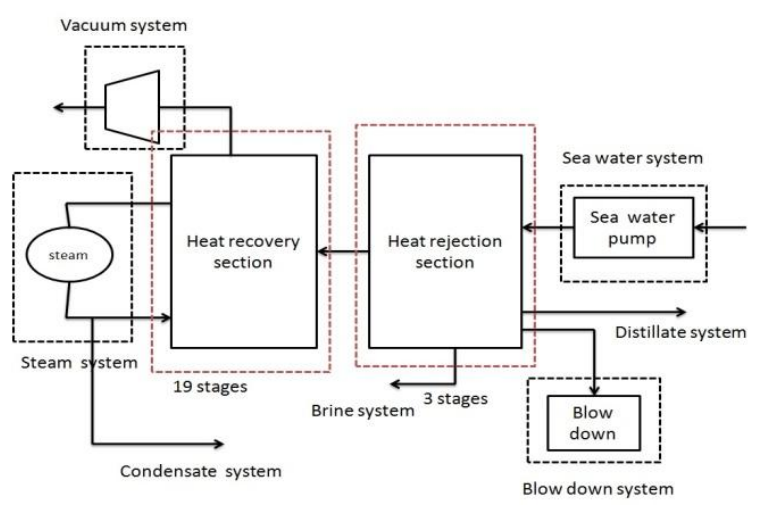

Figure 1 Block diagram of different operational systems in MSF plant

The Multistage glimmer procedure comprises of a few phases with a few procedure factors and the controlled factors. The key factors that decide the presentation of the framework is the Top Brine Temperature. Thus a powerful controller is required to control the TBT which thus upgrades the presentation of the framework. A feed forward with input controller is intended to control the top salt water temperature with steam stream as the control variable and the saline solution stream as the unsettling influence. [8],[ 10] ,[12] 
A neural system (NN) model of the framework has been prepared and tried utilizing trial information intentionally gathered and the $\mathrm{NN}$ model has been utilized for the examination of the procedure execution under different working conditions. On this premise, a control framework that upgrades the distillate creation under factor working conditions has been created, actualized and tried [2]

A model prescient controller was intended to accomplish an assortment of operational goals, for example, boosting distillate generation or execution proportion, limiting vitality utilization, and so forth. CMPC gives set focuses to the current PID controllers and, in this way, honesty with the current instrumentation is kept up. [3]

Various models from the writing are examined and a basic model for control reasons for existing is proposed. At long last, a square situated library for MATLAB/SIMULINK is exhibited, so extraordinary plant setups can be actualized as square graph to reenact the framework and to test control calculations. [4]

The fluffy rationale controller (FLC) is intended for one of the significant circles, in particular the top saline solution temperature (TBT). A lot of fluffy guidelines that make the controller resemble a corresponding in addition to subsidiary controller (PD-like FLC) is gotten and applied to a first request in addition to dead time (FODT) estimation of the plant model. [5]

An exhaustive study is directed on the endeavors made in applying robotization and control methods to MSF Desalination procedures and plants. The study incorporates entrenched old style control techniques just as current additionally encouraging ones. Besides, some proposed new savvy control methodologies are sketched out and their advantages are shown. [6]

A relentless state numerical model is created to break down the MSF desalination process. It depends on an itemized physicochemical portrayal of the procedure, including all the basic rudimentary wonders. [7]

The greater part of theresearchers focus on a solitary variable framework. So as to give significance of multivariable parameters which influences the TBT, another plan is proposed utilizing feed forward and input controller framework consolidating the intercession of steam stream and salt water stream variety to control TBT. [7],[ 9] ,[11]

\section{Conventional Top Brine TEMPERATURECONTROLLER}

The general block diagram of the brine heater with PID controller is shown in figure 2 the top brine temperature depends on the variation of steam flow. In order to obtain greater performance the TBT has to be maintained. The TBT is maintained at the desired set point $\left(90^{\circ} \mathrm{C}\right)$ by the PID controller.

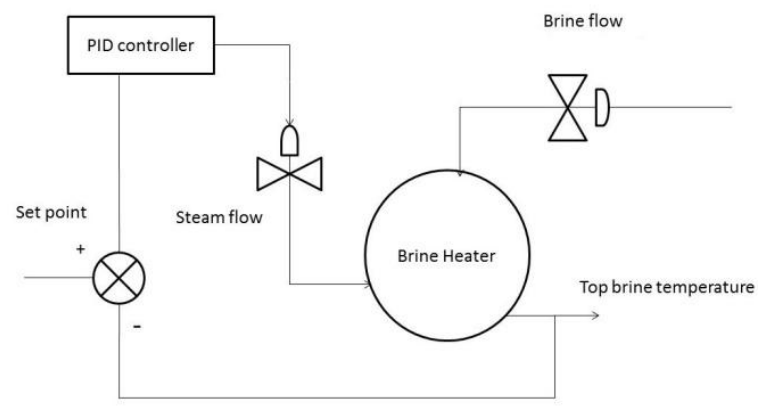

\section{Figure 2 General block diagram of Brine heater with PID controller}

The optimum PID controller parameters obtained by trial and error from the simulation test conducted in the simulation setup for various load conditions with respect to real time data collected from desalination plant are presented in Table 1 .

Table 1 PID parameters

\begin{tabular}{|c|c|c|c|}
\hline \multirow{2}{*}{ Control loop } & \multicolumn{3}{|c|}{ PID parameter } \\
\cline { 2 - 4 } & $\mathrm{K}_{\mathrm{P}}$ & $\mathrm{K}_{\mathrm{I}}$ & $\mathrm{K}_{\mathrm{D}}$ \\
\hline $\begin{array}{c}\text { TBT } \\
\text { Controller }\end{array}$ & 1.80 & 1.0 & 0.3 \\
\hline
\end{tabular}

The PID response that was obtained for various load conditions are shown in figure 3 which shows the temperature raise from $80^{\circ} \mathrm{C}$ to $90^{\circ} \mathrm{C}$. A disturbance is added that causes the temperature to rise to $93^{\circ} \mathrm{C}$ and the effect of the PID controller to bring the TBT back to the set point is shown in fig. 4

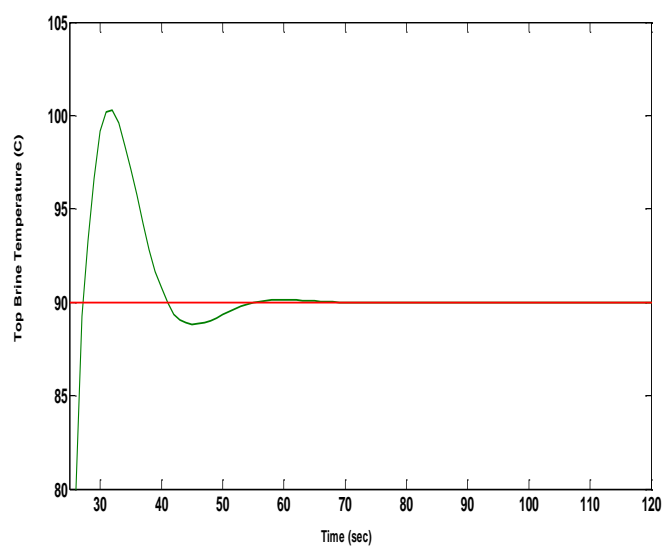

Figure 3 Response of PID $\left(80-90^{\circ} \mathrm{C}\right)$ 


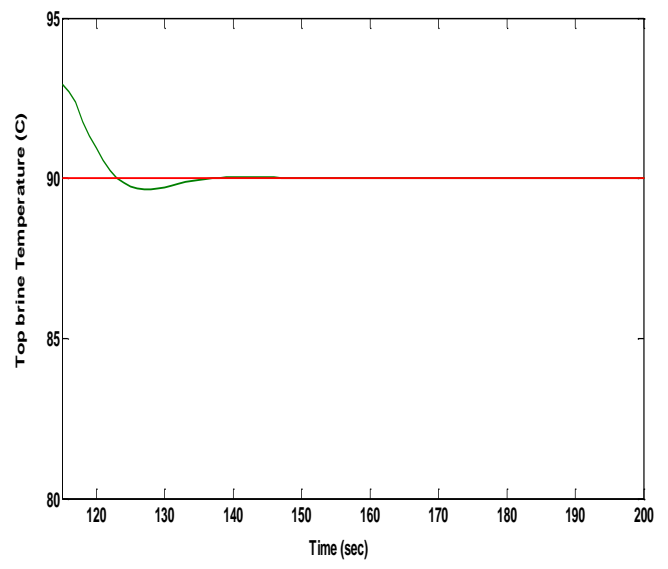

Figure 4 Response of $\operatorname{PID}\left(93-90^{\circ} \mathrm{C}\right)$

Table 2 Performance of the PID controller

\begin{tabular}{|l|c|c|}
\hline & \multicolumn{2}{|c|}{ Step change } \\
\hline & From $80^{\circ} \mathrm{C}$ & From $93^{\circ} \mathrm{C}$ \\
\hline Rise time & 19 & 21 \\
\hline Peak time & 22 & 26 \\
\hline Settling time & 53 & 56 \\
\hline ISE & 9749 & 8634 \\
\hline IAE & 9964 & 9972 \\
\hline
\end{tabular}

The results that were analyzed by using the PID controller from the response are tabulated in table 2

\section{Multivariable Mathematical Model}

In order to improve the performance of multistage flash desalination plant it is necessary to give importance to maintain the Top Brine Temperature, which is the brine outlet from the brine heater $\left(\mathrm{T}_{\mathrm{bo}}\right)$ in a desired value for various load conditions. In the conventional system the desired value of Top Brine Temperature is controlled by adjusting the steam flow input $\left(\mathrm{F}_{\mathrm{si}}\right)$ to the Brine Heater. But this is not sufficient because the variation of Top Brine Temperature may also be affected by brine flow rate $\left(\mathrm{F}_{\text {bin }}\right)$. Most of the research works were not addressed the effect of Top Brine Temperature due to other parameters. So in this chapter we consider the effect o TBT for change in brine flow rate using mathematical model. The schematic diagram of brine heater is shown in figure 5 .

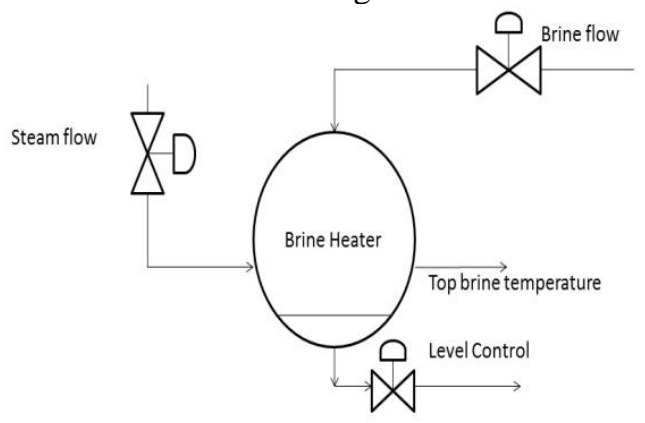

Figure 5 Schematic diagram of Brine Heater

\section{A. Brine - Heater Model}

The mathematical model is obtained from [1]. Some modifications were done to include the effect of the steam flow. It will be assumed that salt concentration and brine flow rate do not change in the brine heater. Thus, the balance equations

$$
\frac{d m_{b}}{d t}=F_{b o u t}(t)-F_{b i n}(t)
$$

Where

$\mathrm{m}_{\mathrm{b}}$ - Mass of Brine $(\mathrm{Kg})$

$\mathrm{F}_{\text {bout }}$ - Brine output flow $(\mathrm{Kg} / \mathrm{sec})$

$\mathrm{F}_{\text {bin- }}$ - Brine feed water $(\mathrm{Kg} / \mathrm{sec})$

The equation for top brine temperature $\left(\mathrm{T}_{\mathrm{b}}\right)$ is given as

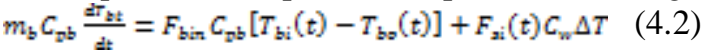

Where

$\mathrm{F}_{\mathrm{si}}-$ Steam flow rate $(\mathrm{kg} / \mathrm{sec})$

$\mathrm{C}_{\mathrm{w}^{-}}$Coefficient of velocity of water

$\Delta \mathrm{T}$ - Difference in temperature of input and output steam

The equation (4.1) can be reduced as

$$
\frac{d T_{b}}{d t}=\frac{F_{b i n} C_{p b} \| T_{b i}\left[(t)-T_{b t}[t] l\right]+F_{s i}(t) C_{w} \Delta T}{m_{b} C_{p b}}
$$

The inlet temperature to the brine heater is $84^{\circ} \mathrm{C}$ the temperature of the sea water is $35^{\circ} \mathrm{C}$. The process parameters are taken from [1]. The process parameters are listed in table 3

\section{B. Variation of Top Brine Temperature:}

The I/O characteristics are determined from equation 4.3 by keeping the brine flow rate constant and varying the steam flow. From the figure 6 it is observed that as the steam flow changes the top brine temperature increases proportionally. The change of temperature is linearly increasing.The I/O characteristics is determined from equation 4.3 by keeping the steam flow rate constant and varying the brine flow From the figure 7 it is observed that as the brine flow changes the top brine temperature decreases. The change of temperature is linearly decreasing

\begin{tabular}{|c|c|c|}
\hline Variables & & Values \\
\hline $\mathrm{m}_{\mathrm{b}}$ & $\begin{array}{c}\text { Mass of the } \\
\text { brine }(\mathrm{Kg})\end{array}$ & 1250 \\
\hline $\mathrm{C}_{\mathrm{w}}$ & $\begin{array}{c}\text { Coefficient } \\
\text { velocity of water }\end{array}$ & 0.97 \\
\hline $\mathrm{C}_{\mathrm{pb}}$ & $\begin{array}{l}\text { Specific } \\
\text { Capacity of Brine }(\mathrm{J} / \\
\mathrm{kg} \mathrm{K})\end{array}$ & 1.064 \\
\hline $\mathrm{F}_{\mathrm{si}}$ & $\begin{array}{cc}\text { Steam } & \text { flow } \\
\text { rate }(\mathrm{kg} / \mathrm{sec})\end{array}$ & 39 \\
\hline$F_{\text {bin }}$ & $\begin{array}{cc}\text { Brine } & \text { flow } \\
\operatorname{rate}(\mathrm{kg} / \mathrm{sec}) & \end{array}$ & 3968 \\
\hline
\end{tabular}

Table 3 Process parameters 


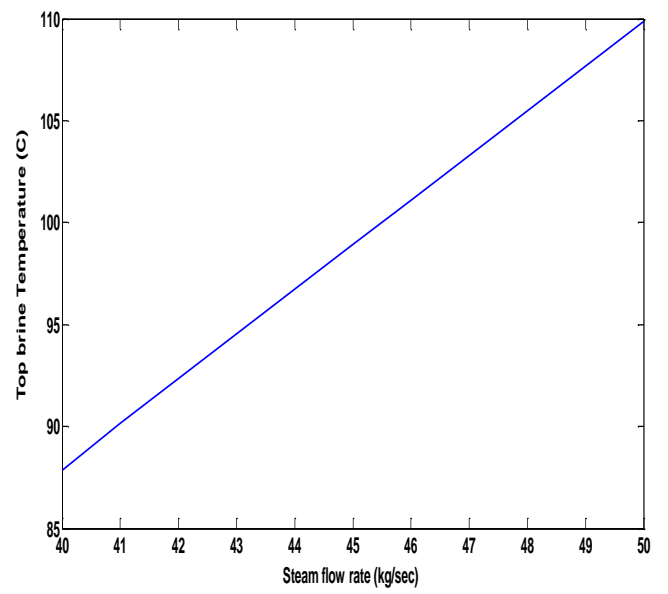

Figure 6 I/O Characteristics between Steam Flow and Top Brine Temperature through model

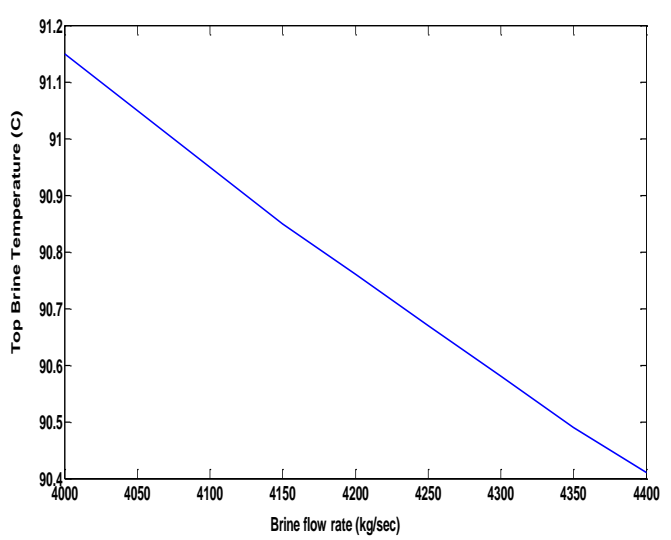

Figure 7 I/O Characteristics between Brine Flow and Top Brine Temperaturethrough model

\section{Proposed Feed forward and feedback controller}

The feed forward with input control has more noteworthy execution contrasted with that of the straightforward criticism controller (PID).The feed forward controller can dispense with the impact of the unsettling influence before it influences the yield to such an extent that the mistakes can be diminished. In the case of displaying mistakes, exists then the feed forward control can lessen the impact of the deliberate unsettling influence on the yield than that of the criticism controller. The bit of leeway utilizing the feed forward control is it has a dependable solidness and the working expense is low. The criticism control framework is essential since it is required to track set point changes and to smother unmeasured unsettling influences that are constantly present in any genuine procedure. Henceforth the feed forward controller is utilized alongside input controller. From the figure 6 and figure 7 it is seen that the top salt water temperature fluctuates with the impact of both steam stream and the saline solution stream. In this structure the impact of steam stream is considered as the information and the impact of the salt water stream is considered as the unsettling influence. The impact of the salt water stream need to wipe out before it influences the procedure, subsequently we are utilizing feed forward controller with input controller.In feed forward with criticism controller two controllers are utilized. One is the PID controller which is utilized for controlling the input circle and the feed forward controller is utilized to control the feed forward circle. The joined square chart of the feed forward with criticism is given in figure 8 . The figure demonstrates that the change in TBT is influenced by the salt water stream (aggravation) and the joined impact of both feed forward and criticism controller are utilized to eliminateit.

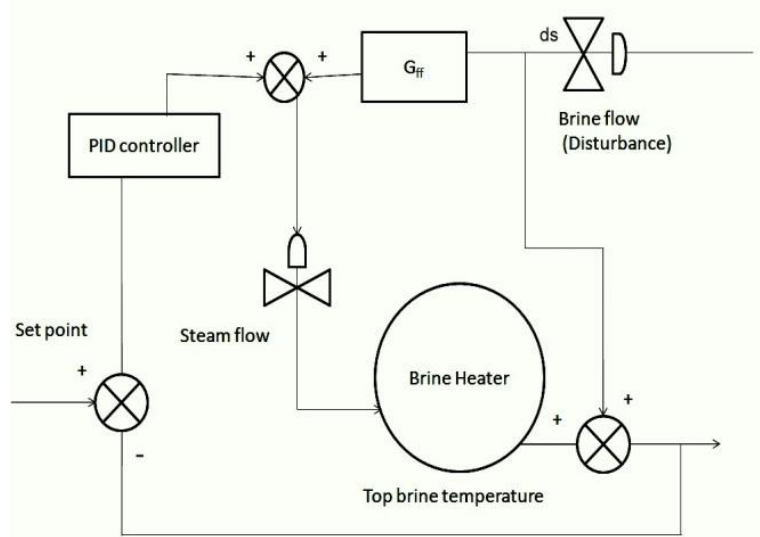

Figure 8 feed forward feedback process diagram

The equation4.3 is used for determining the transfer function. Using the above equation the simulink model is developed and the transfer function is obtained. The table 4 shows the transfer function for steam flow and brine flow relating the TBT.

Table 4 Transfer function for Steam flow and Brine flow relating TBT

\begin{tabular}{|c|c|}
\hline $\begin{array}{c}\text { Steam flow rate and the } \\
\text { Top Brine Temperature }\end{array}$ & $G_{11}(s)=\frac{2.1987}{(1+5.37 s)} e^{-12 s}$ \\
\hline $\begin{array}{c}\text { Brine flow rate and the } \\
\text { Top Brine Temperature }\end{array}$ & $G_{12}(s)=\frac{0.02262}{(1+4.725 s)} e^{-14 s}$ \\
\hline
\end{tabular}

The transfer function $\mathrm{G}_{11}(\mathrm{~s})$ is considered as the process transfer function and the $\mathrm{G}_{12}(\mathrm{~s})$ is considered as the disturbance transfer function. Therelationship of feed forward controller is given as

$$
G_{f f}(s)=-\frac{G_{d}(s)}{G_{p}(s)}
$$

Where

$\mathrm{G}_{\mathrm{ff}}(\mathrm{s})$ - feed forward controller transfer function

$\mathrm{G}_{\mathrm{d}}(\mathrm{s})$ - disturbance transfer function

$\mathrm{G}_{\mathrm{p}}(\mathrm{s})$ - process transfer function

$G_{d}(s)=\frac{0.02262}{(1+4.725 s)} e^{-14 s}$

$G_{D}(s)=\frac{2.1987}{(1+5.37 s)} e^{-12 z}$

The PID controller parameters are mentioned in the table 1 .

\section{RESUlt AND ANALYSIS}

The figure 9 shows the rejection of disturbance. The temperature rises from $80^{\circ} \mathrm{C}$. The feed forward - feedback controller rejects the error and br brings back the temperature to $90^{\circ} \mathrm{C}$.

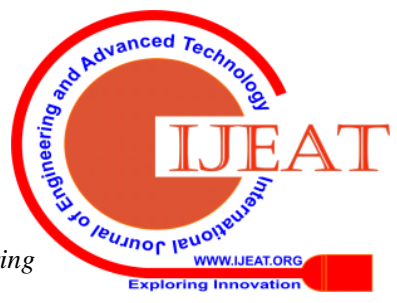




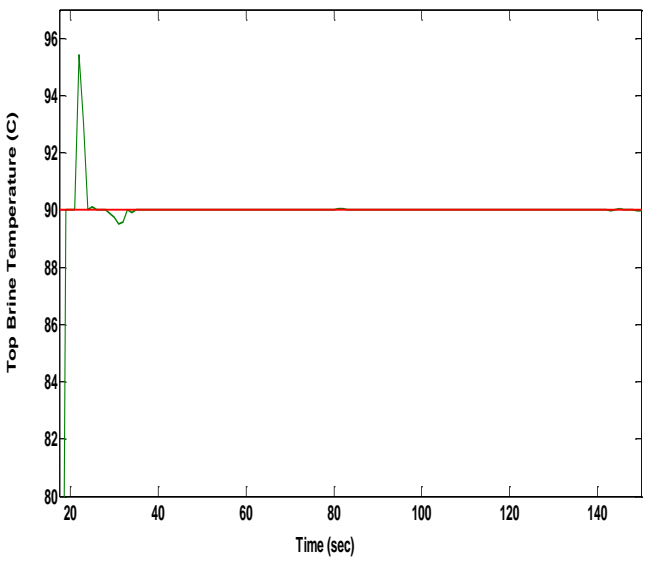

Figure 9 Response of feed forward feedback controller

The figure 10 shows the rejection of disturbance due to the effect of brine flow. The disturbance causes the temperature to rise to $92^{\circ} \mathrm{C}$. The feed forward - feedback controller rejects the error and brings back the temperature to $90^{\circ} \mathrm{C}$.

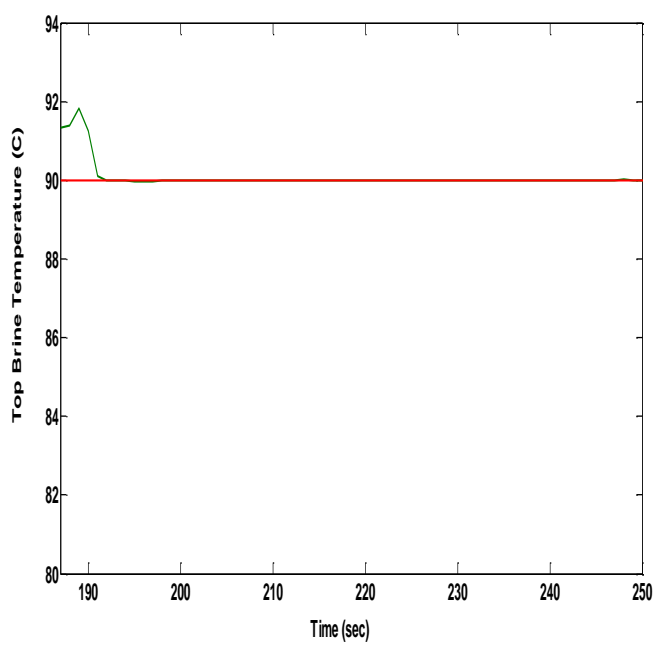

Figure 10 Response of feed forward feedback controller

Table 5 Performance of feed forward feedback controller

\begin{tabular}{|l|l|l|}
\hline & \multicolumn{2}{|c|}{ Step change } \\
\hline & From $80^{\circ} \mathrm{C}$ & From $92^{\circ} \mathrm{C}$ \\
\hline ISE & 2696 & 2703 \\
\hline IAE & 2835 & 2860 \\
\hline Settling time & 50 & 51 \\
\hline
\end{tabular}

From the table 2 and 5, it is observed that the feed forward with feedback controller has better error rejection capacity and the performance is much better than convention PID controllers.

\section{Conclusion}

This paper displayed examinations did on PID and feed forward with input controllers for TBT control. The control goal is to manage steam stream to keep up required TBT independent of the adjustments in the Brine stream. The control plots to be specific traditional PID and feed forward with criticism controllers were structured and recreations were done and the heartiness of the proposed controller plan is exhibited for variety in parameters. The presentation of the control plans is approved quantitatively utilizing both time area particulars just as mistake necessary model. The shut circle reaction of the proposed controller plan indicates palatable transient reaction. The controller yield is smoother with no wavering, which will build the life of the control components. Table 5 shows coming about least ISE and IAE which uncovers the predominance and strength of the proposed plan over the traditional plans.

\section{REFERENCES}

[1] Sharma, R.K., Irusapparajan, G. \& Periyaazhagar, D. 2019, "Three-phase symmetric cascading Z-source seven levels multilevel inverter excited by multi carrier sinusoidal pulse width modulation scheme", International Journal of Innovative Technology and Exploring Engineering, vol. 8, no. 10, pp. 4269-4274.

[2] Velavan, R., Bharanidharan, S. \& Sheeba, B. 2019, "EMF pollution Causes, effects and protection", International Journal of Innovative Technology and Exploring Engineering, vol. 8, no. 9 Special Issue 3, pp. 1166-1168.

[3] Saravana, S., Balaji, S., Arulselvi, S. \& John Paul Praveen, A. 2019, "Reliable power quality monitoring and protection system", International Journal of Innovative Technology and Exploring Engineering, vol. 8, no. 9 Special Issue 3, pp. 644-645.

[4] Tamil Selvan, S. \& Sundararajan, M. 2019, "Performance Parameters of 3 Value 8t Cntfet Based Sram Cell Design Using H-Spice", International Journal of Recent Technology and Engineering, vol. 8, no. 2 Special issue 5, pp. 22-27.

[5] Jac Fredo, A.R., Abilash, R.S., Femi, R., Mythili, A. \& Kumar, C.S 2019, "Classification of damages in composite images using Zernike moments and support vector machines", Composites Part B: Engineering, vol. 168 , pp. $77-86$.

[6] Kathiravan, P. \& Govindaraju, C. 2019, "Design and evaluation of ultra gain isolated DC-DC converter for photovoltaic system", International Journal of Engineering and Advanced Technology, vol. 8, no. 5, pp. 2646-2651.

[7] Kripa, N., Vasuki, R. \& Kishore Kanna, R. 2019, "Realtime neural interface controlled au-pair BIMA bot", International Journal of Recent Technology and Engineering, vol. 8, no. 1, pp. 992-994.

[8] Mohanraj, Meenaa Kumari, M., Philomina, S. \& Jasmin, M. 2019, "In-situ humidity measurement of hydrogen fuel cell car using MEMS sensor", International Journal of Recent Technology and Engineering, vol. 8, no. 1, pp. 41-43.

[9] Velmurugan, T. \& Prakash, S. 2019, "Artificial intelligent based distribution automation of swift fault detection isolation and power restoration for HT network", International Journal of Innovative Technology and Exploring Engineering, vol. 8, no. 6, pp. 1-6.

[10] Dwarakesh, K. \& Prem Kumar, G. 2019, "Five-level inverter based sequential boost system using fuzzy logic controller", International Journal of Innovative Technology and Exploring Engineering, vol. 8, no. 6, pp. 12-19.

[11] Anne Gifta, A. \& Hemavathi, G. 2019, "Analysis of grid tied solar PV system using ANFIS Algorithm", International Journal of Innovative Technology and Exploring Engineering, vol. 8, no. 6, pp. 312-316.

[12] Jayavel, R., Rangaswamy, T.R. \& Prakash, S. 2019, "Efficient grid management system with renewable and conventional power sources", International Journal of Innovative Technology and Exploring Engineering, vol. 8, no. 6, pp. 287-289.

[13] Hemavathi, G. \& Maheshwaran, S. 2019, "Proportional resonan controlled high gain step-up converter system with improved response", International Journal of Innovative Technology and Exploring Engineering, vol. 8, no. 6, pp. 317-323.

[14] Periyaazhagar, D. \& Irusapparajan, G. 2019, "Design and completion of asymmetric single phase 27 level cascaded mli for various pwm scheme", International Journal of Innovative Technology and Exploring Engineering, vol. 8, no. 6, pp. 792-797. 
[15] Mahalakshmi, V. \& Vijayaragavan, S.P. 2019, "PV based power electronic converters for high voltage DC applications", International Journal of Recent Technology and Engineering, vol. 7, no. 6, pp. 670-674.

[16] Irusapparajan, G., Periyaazhagar, D., Prabaharan, N. \& Rini Ann Jerin, A 2019, "Experimental verification of trinary DC source cascaded h-bridge multilevel inverter using unipolar pulse width modulation", Automatika, vol. 60 , no. 1 , pp. 19-27

[17] Sangeetha, G., Sherine, S., Arputharaju, K. \& Prakash, S. 2019, "On Line Monitoring of Higher Rated Alternator using Automated Generator Capability Curve Administer", Proceedings of the IEEE International Conference on \&amp;quot;Recent Trends in Electrical, Control and Communication\&amp;quot; RTECC 2018, pp. 176.

[18] Bycil, V.J. \& Wiselin, M.C.J. 2019, "Modeling and analysis of vibration energy harvesting system using piezo stack", International Journal of Mechanical and Production Engineering Research and Development, vol. 9, no. Special Issue 1, pp. 523-533.

[19] Sripada, A., Warrier, A., Kapoor, A., Gaur, H. \& Hemalatha, B. 2018 , "Dynamic lateral balance of humanoid robots on unstable surfaces", International Conference on Electrical, Electronics, Communication Computer Technologies and Optimization Techniques, ICEECCOT 2017, pp. 539.

[20] Srinivasan, S., Thirumalaivasan, K. \& Sivakumaran, T.S. 2018 , "Performance evaluation of double-output luo converters", Journal of Advanced Research in Dynamical and Control Systems, vol. 10, no. 10 Special Issue, pp. 870-878.

[21] Karthikayen, A. \& Selvakumar Raja, S. 2018, "A skellam distribution inspired trust factor-based selfish node detection technique in MANETs", Journal of Advanced Research in Dynamical and Control Systems, vol. 10, no. 13 , pp. $940-949$.

\section{AUTHORS PROFILE}

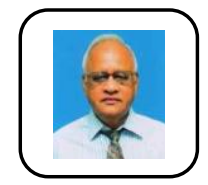

Dr.T.R.Rangaswamy, Professor,Department of EEE,Bharath Institute of Higher education and research, Tamilnadu, India

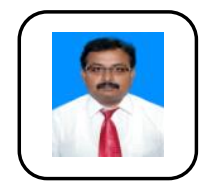

Dr.S.Prakash, Professor,Department of EEE, Bharath Institute of Higher education and research, Tamilnadu, India

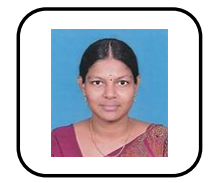

Rathika R, Assistant Professor,Department of EEE Bharath Institute of Higher education and research, Tamilnadu, India 